\title{
The Effect of Banking Relationship on Firm Performance in Vietnam
}

\author{
Vu Huu Thanh ${ }^{1} \&$ Nguyen Minh $\mathrm{Ha}^{1}$ \\ ${ }^{1}$ Graduate School, Ho Chi Minh City Open University, Vietnam \\ Correspondence: Nguyen Minh Ha, Graduate School, Ho Chi Minh City Open University, 97 Vo Van Tan Street, \\ District 3, Ho Chi Minh City, Vietnam. Tel: 84-8-3930-0947. E-mail: ha.nm@ou.edu.vn or ngmiha@yahoo.com
}

Received: March 10, 2013

Accepted: March 29, 2013

Online Published: April 18, 2013

doi:10.5539/ijef.v5n5p148

URL: http://dx.doi.org/10.5539/ijef.v5n5p148

\begin{abstract}
The objective of this paper is to examine how banking relationship influences on performance of public listed firms in Vietnam. With a sample of 465 companies listed in Vietnam observed in period $2007-2010$ and using regression method, the research finds that firm performance decreases as the number of bank relationships increases. If a firm establishes strongly short-term credit financing relationship with banks, the firm's performance reduces. On the contrary, if a firm has strongly long-term credit financing relationship with banks, its performance increases. The effectiveness of using total assets is worse as a firm has strongly overall credit financing relationship with banks. Additionally, the study also indicates that asset tangibility structure has negative relationship with firm's ROE, while assets have negative association with ROA. Turnover has positive association with firm performance. Finally, firms with higher state shares have less effective than ones with lower state shares.
\end{abstract}

Keywords: banking relationship, credit, firm performance, financing

\section{Introduction}

The previous studies on firm performance show that factors such as debt, growth, size and structure of assets of a firm, and the accessibility to bank loans, have certain influence on the firm performance. On the other hand, the firms' performance is affected by the close relationship between banks and firms. Firm's banking relationship is important role for firm's performance such as to improve business reputation, to increase accessibility to loans, to reduce the negative effect of asymmetric information, and to decrease the interest costs.

In Vietnam, there are a small number of firms listed on the stock market. The listing helps them have other funding channel. However, funding from banks still plays particularly important role in the maintenance and growth of firms. Building up strong banking relationships helps firms take certain advantages. At the present, Vietnam's economy has been a transition economy. Since the mid-1980s, through reform period ("Đổi Mới" period), Vietnam has made a shift from a highly-centralized planned economy to a socialist-oriented market economy. The government still controls many areas of the economy. In this transition process, the financial market of Vietnam is imperfect and the shadow of state monopoly, of cause, still presents in fields. Due to above characteristics, opportunities of private firm in accessing bank funding become harder than firms having large state - owned equity. In recent years, the State Bank has taken control of credit growth to curb inflation, this leads to difficulty for firms in accessing loans from banks. In such conditions, any firm being able to access easily bank loans will take more advantages or have growth opportunities than others, especially those originate in state firms or have large ratio of state - owned equity. A question can be posed in this condition: Do firms having better banking relationship actually operate more effectively than others? This is also one of the interesting reasons for the research paper and this question will be answer in this study.

There are a lot of empirical studies of banking relationships on firm performance in developed countries. However, this, to our knowledge, is not any research of this topic in Vietnam (a new developing country). Hence, the purpose of this paper is to analyze the firm's banking relationship affect firm performance in Vietnam and to suggest policy implications related to the firm's banking relationship. The method applied is regression with panel data. The data is the firm-level panel data in Vietnam covering the period from 2007-2010, consisting of 465 companies listed.

The rest of this paper is organized as follows: The next section gives a brief literature review. Section 3 present the methodology and research model, and Section 4 analyze empirical results. Finally, Section 5 concludes the 
paper and gives recommendations.

\section{Literature Review of Banking Relationship and Firm Performance}

The banking relationship includes two kinds: deposit relation and lending relation. However, this research concentrates on the lending relationships. Banking relationships are expressed through the number of banking relationships, duration of banking relationship, the amount of credit (Peltoniemi, 2004), interest (Bolton and Freixas, 2000), and banking services (Degryse and Cayseele, 2000).

From firm's perspective, establishing good relationships with banks will help firms to enhance business reputation, to reduce the leakage of information to competitors (Campbell, 1979), to decrease the negative impact of asymmetric information (Diamond, 1984 and 1991; Fama 1985; Rajan, 1992, Holmstrom and Tirole, 1997, and Bolton and Freixas, 2000), to reduce agency conflicts related to financial intermediation (Deloof and Vermoesen, 2010), to increase accessibility to loans, and to reduce the interest cost (Houston and James, 1996; Pertersen and Rajan, 1995). This leads to less dependence of firms on the liquidity of cash flow within the firms. Hence, firms can easily invest in fixed assets with lower cost of capital, and reserves cash will be further optimized to increase profitability (Fazzari et al., 1988; Hoshi et al., 1990; and Ramirez, 1995). Shen et al. (2004) argue that when a firm has a strong banking relationship, firm's investment is less sensitive to cash flow. Diamond (1984) finds that a close relationship allows the bank to undertake an active monitoring role which can alleviate problems related to free-riding and information asymmetry. In addition, when firms establish close banking relationship through repeated lending from a bank, they will increase their prestige on the various funding channels. Diamond (1991) also indicates that firms choose bank funding first in order to establish sufficient credibility and then access the capital markets. Kutsuna et al. (2003), researching impact of banking relationships to access the capital markets of Japanese firms, find that when firms build good relationships with commercial banks, they increase accessibility to equity capital markets. Furthermore, building up close relationships with banks helps firms overcome financial or business distress (Hoshi et al., 1990). Finally, many empirical researches have evidences of effects of banking relationship on firm performance.

However, firms not only get the benefits from establishing close relationships with banks, but also face certain risks. Dass and Massa (2006) point out that through the bank lending activity, banks act as "insiders". They play a supervisory role and do not encourage managers to accept investments in high risk projects. This cause firms not to achieve profit breakthrough, and then their stock prices will become more stable. Thus, the stock liquidity will be reduced.

In the process of building sustainable relationships, banks hold a lot of information (especially the sensitive and important information) related to the firms performance, the banks will disclose information to competitors intentionally or unintentionally. This problem will become more serious (Berger and Udell, 1998). The more long term relationships firms build, the more monopoly information banks increasingly require. This may allow banks to ask firms about higher interest rate and more collateral in the future (Suwannaporn, 2003). Greenbaum et al., (1989), Sharpe (1990), Thadden (1995) and Rajan (1992) agree with this view and argue that when banks are capable of observing confidential information from the borrower, it can cause a lock-in problem. It means that firms can not release the information to other financial institutions to set up credit relationship with them, and then they have to face to the hold-up problem. This creates a switching cost, or losses valuable investment opportunities.

Small firms usually tend to switch banks, especially when they have growth opportunities (Farinha and Santos, 2001). In order not to lose power of governing firms, banks tend to restrain their expected growth (Gambini and Zazzazo, 2009). In another aspect, when firms have long-term banking relationship, they will easily be funded to overcome distress. Banks may decide to extend further loan in order to recover its previous loan (Boot, 2000). Then, the soft-budget constraint problem occurs when firms rely on others and lack of effort to prevent the negative effects since they expected that banks will help them eventually.

The impact of banking relationships on business performance under some angles as follows:

Banking relationship increases the value of shareholder's equity: James (1987) argues that when firms announce publicly on the new loan contracts or the extension of banks credit, their stock price will increase. This finding reinforces Fama's research (1985) when he says the bank's loans provide firms a degree of certainty about future cash flow. James and Weir (1990), and Slovin and Young (1990) conclude that if firms have bank lending relationship, initial public offerings (IPOs) will be less underpriced than IPOs for others. Billett et al. (1995) explore the relationship between lender quality and loan announcement - day return. They find that if firm borrows from the higher quality lender, loans are associated with positive and statistically significant price reaction. Conversely, loans announcement from the lower quality lender has negative impact on price. These 
show that the value of shareholder's equity will increase when firms establish good banking relationships.

Banking relationships impact on firm investment: Studies of Fazzari et al. (1988), Hoshi et al. (1990), Ramirez (1995), and Shen et al. (2004) point out that creating a good relationship with bank will improve the financial structure of the business. However, the more close relationships with banks firms have, the more they get dominated by banks through their supervisory activities. Banks are less likely to encourage firms to make decisions to invest in risk areas, therefore it is difficult for firms to expand scale. This becomes true if firm size is small (Dass and Massa, 2006) or firm depends on credit of a main bank (Gambini and Zazzazo, 2009).

Banking relationships influence business performance and growth: Banking relationship has different impacts on firm performance and growth. Rajan (1992) finds out that firms can settle hold - up problem by setting up multiple bank relationships. Hiraki et al. (2003) reinforce this view that if firms belong to a main bank relationship, their profit will decrease; on the contrary, multiple main bank relationships will reduce the hold up cost and lead to higher profitability. However, multiple bank relationships can be costly (duplicated monitoring, free rider problems, or restructuring of debt claim) and bring about decrease in profitability. Castelli et al. (2006) demonstrates that firms' profitability (ROE and ROA) decreases as the number of bank relationships increases. Fok (2004), using sample of Taiwanese firms around the 1997 Asian financial crisis, points out a negative relation between firm performance and the number of domestic-bank relationships, but a positive relation between firm performance and the number of foreign-bank relationships. Yosha (1995) and Degryse and Ongena (2001) argue that if firms disclose proprietary information to creditors, firms establishing bilateral bank relationship will gain higher sales profitability than those establishing multilateral bank relationship.

Studies in effects of duration bank relationship on firms' performance and growth are given various results. Gambini and Zazzazo (2010) investigates Italian manufacturing firms in the period 1998 - 2003 and shows that small firms maintaining stable credit relationship with a main bank during the three-year survey (long-lasting bank ties) grow less than bank-independent small firms; however, long-lasting bank ties of medium firms have a positive relation with growth. Castelli et al. (2006) find that sales over assets has quadratic function relation with duration bank relationship, the more longer duration firms get, the more firm sales over assets decreases.

The study of Hiraki et al. (2003) is the one of the rare studies on bank loans quantity. They show negative relation between total main bank loans to total liabilities and ROA, and conclude that the hold - up costs of main bank relationships damage the profitability of the firm.

\section{Methodology and Research Model}

\subsection{Methodology}

Research data in the paper are presented in panel data. By using panel data regression, we decide between fixed or random effects through running a Hausman test where the null hypothesis is that the preferred model is random effects versus the alternative the fixed effects (Baltagi, 2005; and Park, 2009).

\subsection{Research Model}

The performance of firms may be affected by two main factors: (i) banking relationship, and (ii) firm characteristics. Banking relationship can include some variables like number of bank relationships, credit financing relationships or loan bank relationships, duration of bank relationships, bilateral and multilateral bank relationships. Besides, firm performance also is affected by firm characteristics like age, size, growth or tangible asset structure.

In this study, banking relationship factors include: (i) Number of bank relationships and (ii) Credit financing relationships. If firms are provided a large amount of credit, the firms have strong credit relationships. This study uses factor of "credit financing relationships" calculated as follows: First, the ratio of short-term or/and long-term bank loans to total liabilities of a firm are calculated; and then, the average ratio of short-term or/and long-term bank loans to total liabilities of all firms in sample research are estimated. Thus, there are three variables: short-term credit financing relationships, long-term credit financing relationships, and overall credit financing relationships. If each ratio of a firm is greater than average ratio corresponding, it means that this firm has a significant involvement of bank loans (short-term, long-term or overall) than others, and this variable takes value 1 . By contrast, this takes value 0 . Thus, these variables are dummy ones classifying the strength or weakness of relationship through amount of credit provided.

Firm characteristics used in this research contain variables as follows: age, size, tangible asset structure and type of ownership. The dependent variables demonstrating firm performance are return on assets (ROA) and return on equities (ROE). 
There are two general models to examine two cases as follows:

Case 1: Analyzing the impact of the number of bank relationships, short-term credit financing relationship and long-term credit financing relationships on the firms' performance. The model is given by:

Profit $=f$ (number of bank relationships, short-term credit financing relationship, long-term credit financing relationships, age, size, tangible asset structure and type of ownership).

Case 2: To understand the impact of the number of bank relationships and overall credit financing relationships (both short and long term) on the firms' performance. The model is as follows:

Profit $=f$ (number of bank relationships, overall credit financing relationships, age, size, tangible asset structure and type of ownership).

\subsection{Measuring Variables}

Dependent variables: Firm performance is measured by its profit, including the two sub-variables: ROA and ROE. ROE is equal to return after tax on equities, and ROA is equal to return before tax on assets.

Independent variables: Banking relationship variables are main independent variables. They contain four variables: number of bank relationships, short-term credit financing relationship, long-term credit financing relationships and overall credit financing relationships.

(i) Number of bank relationships (Banknumber and [Banknumber $]^{2}$ ): This variable has quadratic function relation with dependent variable (Castelli et al., 2006). This means that when firms increase number of bank relationships, they will increase the power of negotiation, reduce hold-up cost, easily get more loans for investment, and improve the liquidity of cash flow, resulting firms' performance increase (measured by Banknumber variable). However, if firms setting up so many number of bank relationships, they will bear the raise of transaction costs and representative costs. These cost outweigh from positive effects above, so they make reduction of profits (measured by [Banknumber $]^{2}$ variable). Banknumber variable is defined as total of number banks lending firms loans in fiscal year. [Banknumber] $]^{2}$ is equal to Banknumber squared.

(ii) Short-term credit financing relationships (ShortRelation): This is a dummy variable and is determined that if the ratio of short-term bank loans to total liabilities of a firm is greater than the average ratio of short-term bank loans to total liabilities of all firms, it takes value 1. Otherwise, it gets value 0 . This variable is equal to one, meaning that the firm has a significant using of bank loans than others. Although firms create the strong relationship with banks, they take advantage of this relationship to handle short-term business problem through short-term overfunding. This demonstrates that when firms are under-pressure by liquidity of cash flow, or concentrate on overgrowth in short - term, they have to accept the increase in financing cost. It is expected that ShortRelation variable associates negatively to firm performance.

(iii) Long-term credit financing relationships (LongRelation): This is a dummy variable and is determined as follows: if the ratio of long-term bank loans to total liabilities of a firm is greater than the average ratio of long-term bank loans to total liabilities of all firms, it takes value 1 and otherwise, it take zero. When the variable is equal to one, it means that the firm has stronger long-term credit financing relationships than others. The long-term loans will promote the sustainable long-term investment activities of firms, and create their effective performance. LongRelation impact is expected to be positive on firm performance.

(iv) Overall credit financing relationships (CreditRelation): It is a dummy variable and is defined that if the ratio of total bank loans to total liabilities of a firm is greater than the average ratio of total bank loans to total liabilities of all firms, it will be equal to one and otherwise is zero. Establishing strong overall credit of banking relationship helps firms improve their liquidity of cash flow and financing easily their business or investment. Therefore, there may be existence of positive influence between CreditRelation and firm performance.

Besides banking relationship variables, there are firm characteristics variables, including:

(i) Firm size: This variable is measured by the logarithm of total assets (LnAsset) and logarithm of turnover (LnTurnover). It is expected that firm's size associates positively to firm's performance because following reseons: First, small firms are less likely to be close to the minimum efficient scale needed to operate efficiently in a market (Audretsch and Mahmood, 1994; and Geroski and Mata, 2005). Second, small firms apply different technologies in accordance with their size. Due to small scale, they use less capital intensive approaches, so variable costs achieve a higher ratio within the total costs of the firm. In a case of lowering prices, small firms find it difficult to bear these costs for a long time; thus, they are less efficiency (Matta and Portugal, 1994 and Petrunia, 2002). Furthermore, small firms' market power is weak, and their operations are in niche markets, which are uncertain. They are more vulnerable to temporary demand shocks and the uncertainties of the market 
than large firms (Dhawan, 2001). Moreover, small firms are typically less diversified than larger firms, which may deteriorate their survival prospects by increasing risk and failing to keep alive options in a fiercely competitive market (Geroski and Mata, 2005).

(ii) Firm age: It is measured by the logarithm of the number of years since the inception of the firm to the observation date, including variables: LnAge and $[\text { LnAge }]^{2}$. Stinchcombe (1965) shows that older firms can gain experience-based economies. It expects that there is a positive relationship between LnAge and firm's performance, but a negative relationship between $[\mathrm{LnAge}]^{2}$ and firm performance.

(iii) Asset Tangibility structure: It is measured by the ratio of fixed assets to total assets. Firms retaining large investments in tangible assets will have smaller costs of financial distress than firms relying on intangible assets (Akintoye, 2008). Thus, asset tangibility is expected to associates positively to firm performance.

(iv) State Ownership: This variable represents the state ownership. State ownership is a specific characteristic of companies listed on Vietnam's stock market. State ownership characteristic includes two variables: Statel and State2. State1 is equal to 1 if the state owns more than $35 \%$ firm's equity, and otherwise it is zero. State 2 takes value 1 if the state owns from $5 \%$ to $35 \%$ firm's equity, otherwise it takes value zero. If the state's equity represents only $0 \%$ to $5 \%$, the state is only a small shareholder (Vietnamese Securities Law, 2010), and it has less power of voting/vetoing. If the state owns from 5\% to $35 \%$ firm's equity, the state is a major shareholder, but it is not strong enough to veto on any business issues of firm (Vietnam law on enterprise, 2005). If the state holds shares of $35 \%$ or more, the state is a major shareholder and has enough power of vetoing on any business issues of firm (Vietnam law on enterprise, 2005). In state firms, the capital is from the government (the state), and a firm's managers are not its owners, so the responsibility of efficiency in state firms is generally lower than it is in other types of firms. Besides, state firm's organization is bulky and higher costs, and these firms have less profit. From above reasons, firms with higher state shares are influenced more by operation styles of state firms, and so they are less efficiency. Thus, state ownership variables (State1 and State2) may impact negatively on firms' performance.

\subsection{Study Data}

The study data includes 465 out of 671 non- financial firms listed on the HOSE (Ho Chi Minh Stock Exchange) and HASE (Ha Noi Stock Exchange) of Vietnam from 2007 to 2010. Sample rate reached 69.3\% of population (465/671) - relatively large sample ratio. This study excludes financial institutions such as investment funds, insurance firms, and securities firms from the sample because their asset and capital structure have different characteristics to non- financial firms.

Up to April, 2011, the total of number of banks working with the analyzed companies is 61, in which 5 banks of State Development and Policies, 37 banks of Joint - Stock Commercial, 6 banks of Joint - Venture, and 13 banks of $100 \%$ foreign capital and foreign bank branches.

\section{Empirical Results}

\subsection{Statistical Description}

Table 1 shows the statistical description of variables in the sample. The average number of banks companies have lending relation is 2.65 and the maximum number of banks companies have lending relation is 8 . The ratio of short-term bank loans to total liabilities of firm that is greater than the average ratio of short-term bank loans to total liabilities is $57 \%$. Similarly, the ratio of long-term bank loans to total liabilities of firm that is greater than the average ratio of long-term bank loans to total liabilities is $41 \%$. The average asset tangibility structure is 0,21 . The number of firms holding state shares of $35 \%$ or more is $18 \%$, the number of firms having state shares of from $5 \%$ to below $35 \%$ is $38 \%$, and the number of firms owing state shares below $5 \%$ is $44 \%$. The ratios of ROA and ROE are $9 \%$ and $17 \%$, respectively.

\subsection{Empirical Result Analysis}

There are two popular models used to estimate panel data: fixed effects model (FE) and random effects model (RE). To decide between fixed or random effects, a Hausman test is run. The Hausman specification test compares fixed effect and random effect models. With null hypothesis, a random effect model is preferred, and vice versa. Hausman test results of two regression cases are summarized in Table 2.

According to analysis results in table 2, the coefficient Prob (chi2) are less than 0.05. It means that Hausman test is significant at $5 \%$ level (rejecting the hypothesis $\mathrm{H}_{0}$ ). Thus, it is better to use fixed effects model to estimate two regression cases. Table 3 provides the results of the regression of the two performance measures (ROA and ROE) in four specificaitons. 
Table 1. The statistical description of variables

\begin{tabular}{llllll}
\hline Variables & Obs & Mean & Min & Max & Std. Deviation \\
\hline Banknumber & 1860 & 2.65 & 0 & 8.00 & 1.53 \\
Banknumber $^{2}$ & 1860 & 9.36 & 0 & 64 & 10.37 \\
Short Loan Credit & 1860 & 99.45 & 0 & 3,513 & 246.22 \\
Long Loan Credit & 1860 & 102.74 & 0 & 8,108 & 494.16 \\
Total Loan Credit & 1860 & 202.19 & 0 & 10,772 & 630.38 \\
Short Relation (dummy) & 1860 & 0.57 & 0 & 1 & 0.49 \\
LongRelation (dummy) & 1860 & 0.41 & 0 & 1 & 0.49 \\
CreditRelation (dummy) & 1860 & 0.30 & 0 & 1 & 0.46 \\
Tang & 1860 & .21 & .00 & .98 & .20 \\
LnTurnOver & 1859 & 26.33 & 20.13 & 30.34 & 1.41 \\
LnAge & 1860 & 2.59 & .00 & 4.42 & .79 \\
LnAge & 1853 & 5.18 & 0 & 8.84 & 1.59 \\
LnAsset & 1860 & 26.50 & 21.07 & 31.09 & 1.34 \\
State 1 & 1860 & .18 & 0 & 1 & .38 \\
State 2 & 1860 & .38 & 0 & 1 & .49 \\
State 3 & 1860 & .44 & 0 & 1 & .496 \\
ROA & 1860 & .09 & -.33 & 2.77 & .13 \\
ROE & 1860 & .17 & -1.34 & .75 & .14 \\
\hline
\end{tabular}

Observing estimation results of four specifications (I, II, III and IV) in table 3, the all significance value of the F statistics of these models are less than 0.05 , which means that at least one coefficient at each specification is different from 0 . These results indicate that the overall models are statistically significant. Additionally, all significance value of the Wald statistics of four specifications are less than 0.05 , so we reject the null hypothesis of homoskedasticity (the null is heteroskedasticiy) at four specifications. The two R Squares, the coefficient of determination, at specification I and III show that more than half the variation in ROE and ROA is explained by the model. However, R Squares in specification II and IV show that nearly half the variation in ROE and ROA is explained by the model.

The effects of the independent variables on firm performance described in table 3 are as follows:

The impact of the number of bank relationships (Banknumber) on firm performance: This variable is statistically significant in all four specifications and has negative relation to ROA and ROE. Castelli et al. (2006) find the negative influence between number of bank relationships and firm performance. While Garriga (2006) points out the opposite. The estimation result of this research is similar to Castelli's result. Although increase in number of bank relationships helps firms increasing in number of credit supply resources and solving the hold-up problem, firms may face to the rise of transaction costs, representative cost and free-riding problem. Moreover, firms in Vietnam have to accept high interest rate in this period (normally, if firms increase number of bank relationships, they will increase the power of negotiation. Thus, they may get lower interest rate). In the period $2008-2010$, Vietnam economy faced galloping inflation, so the government had to use monetary policy tightening in attempt to curb inflation. This leaded to the increase in interest rate. The rate sometimes reached $24 \%$ per year.

Like a coin with two sides, increasing the number of banks in banking relationship help firms easily find more source of funding, but this makes firm easily use credit provided to business activities not appraised carefully. In fact, if the firm gets credit financing from a previous bank, the next banks will become more easily to provide credit to the firm because they often rely on the evaluation of the previous bank. Consequently, the business may operate ineffectively. Hence, the negative effects of increasing the number of banks (transaction costs, free-riding problem, high borrowing cost...) outweigh the positive effects. This explains the existence of negative relation between number of bank relationships and firm performance.

Table 2. Hausman test results of two regression cases

\begin{tabular}{llllll}
\hline No. & Cases & Dependence & Chi2 & Prob(chi2) & Model choice \\
\hline \multirow{2}{*}{ 1. } & \multirow{2}{*}{ Case 1 } & ROE & 35.48 & 0.0012 & Fix Effect \\
& & ROA & 43.34 & 0.0001 & Fix Effect \\
2. & Case 2 & ROE & 23.20 & 0.0394 & Fix Effect \\
& & ROA & 70.44 & 0.0000 & Fix Effect \\
\hline
\end{tabular}


Table 3. The results of the regression

\begin{tabular}{|c|c|c|c|c|}
\hline & \multicolumn{2}{|l|}{ Case 1} & \multicolumn{2}{|l|}{ Case 2} \\
\hline & ROE & ROA & ROE & ROA \\
\hline & $I$ & II & III & $I V$ \\
\hline $\mathrm{R}^{2}$ & 0.65 & 0.43 & 0.56 & 0.47 \\
\hline Prob(Hausman Test) & 0.0012 & 0.0001 & 0.0394 & 0.0000 \\
\hline Prob(F-Test) & 0.0000 & 0.0000 & 0.0000 & 0.0000 \\
\hline Prob(Wald - Test) & 0.0000 & 0.0000 & 0.0000 & 0.0000 \\
\hline Banknumber & $-0.055 * * *$ & $-0.023 * * *$ & $-0.066 * * *$ & $-0.027 * * *$ \\
\hline [Banknumber]2 & -0.0002 & -0.0001 & 0.0003 & -0.0001 \\
\hline ShortRelation & $-0.036 * * *$ & $-0.016 * * *$ & & \\
\hline LongRelation & $0.020^{*}$ & -0.001 & & \\
\hline CreditRelation & & & 0.003 & $-0.014 * * *$ \\
\hline Tang & $-0.046^{* *}$ & -0.021 & $-0.045^{*}$ & -0.018 \\
\hline LnTurnOver & $0.009^{*}$ & $0.015^{* *}$ & $0.01 *$ & $0.015^{* *}$ \\
\hline LnAge & 0.620 & 0.444 & 0.553 & -0.42 \\
\hline LnAge2 & -0.321 & -0.219 & -0.292 & -0.209 \\
\hline LnAsset & 0.009 & $-0.020 * * *$ & $0.011 *$ & $-0.018^{* * *}$ \\
\hline Year2007 & 0.009 & -0.004 & 0.008 & -0.003 \\
\hline Year2008 & 0.008 & -0.0002 & $0.010^{*}$ & 0.001 \\
\hline Year2009 & 0.006 & -0.0001 & $0.010^{* *}$ & 0.011 \\
\hline State1 & $-0.027^{*}$ & $-0.018^{*}$ & $-0.030^{*}$ & $-0.018^{*}$ \\
\hline State2 & $-0.022 *$ & -0.006 & $-0.027^{*}$ & -0.007 \\
\hline Cons & -0.85 & $0.29 * *$ & -0.109 & $0.25 * *$ \\
\hline
\end{tabular}

Notes: $(* * *)$ Significant at $1 \%$ level, $(* *)$ Significant at $5 \%$ level, $(*)$ Significant at $10 \%$ level.

The impact of short-term credit financing relationship on firm's performance: This variable is statistically significant in the specification I and II. Theoretically, when firms establish strong short-term credit financing relationships, they have opportunity to achieve more effectively short-term business activities; thereby this affects firm performance on overall. In fact, there are no previous experimental studies on effects of short-term credit financing relationships to firm performance. Hiraki et al. (2003), use the ratio total main bank loans to total liabilities to estimate their models, find this variable has negative relationship to firms' performance. This study in Vietnam uses short-term credit financing relationships to estimate the banking relationships in models. This empirical result shows that there is a negative impact of short-term credit financing relationship on firm performance. It is likely that firms having strong short-term credit financing relationships are less effective than the others. This is likely explained that Vietnam firms focusing on overgrowth (or short-term growing too fast) are not effective in the period $2007-2010$ when the global financial crisis and domestic economic distress are happening. The effort of speeding up activities in the short-term is ineffective when market purchasing power declines seriously. Therefore, firms fall into distress condition and face short-term cash flow pressures. Additionally, having strong short-term credit financing relationship (it may be a sign of falling into distress) helps firms solve hold-up problem in short-term, but firms have to accept higher borrowing cost in trade-off. Finally but not last the last, in fact, some firms usually use short-term loans to cover to long-term businesses. Above reasons explains why the short-term credit financing relationship associates negatively to firm performance.

The impact of long - term credit financing relationship on firm performance: This variable is used in specification I and II to explore the effect of long-term credit financing relationship to firm performance. This research finds out that firms having strong long-term credit financing relationships are more effective than other firms. It's likely that concentrating on long-term growth through long-term investment helps firm create sustainable performance. This result also shows that the speed of increase in return after tax is more rapid than the speed of increase in equity to firm having strong long-term credit financing relationship. This implies that firms having the strong relationship use financial leverage better than other firms.

There is no statistically significant relationship between this variable and ROA. It means that there is no difference in ROA between firms having strong long-term credit financing relationships and the others. It may conclude that firms establishing strong long-term credit financing relationships use financial leverage (in long term loans) better, but their effectiveness of using total assets is not significantly better. These lead to the 
difference in ROE but the indifference in ROA between two groups of firms.

The impact of overall credit financing relationship on firm performance: This variable is used in specification III and IV to examine the influence of overall credit relationship to firm performance. Theoretically, if firms achieve strong overall credit financing relationship, firms will have more opportunities to get profit. This study do not find out the statistically significant difference in ROE between firms having strong overall credit financing relationships and the remaining firms (specification III). However, this variable is statistically significant in specification IV, showing difference in ROA between the two groups of firms. It's likely that an increase in assets through credit financing reduces effectiveness of using total assets in general.

The impact of tangible asset on firm performance: Son (2003), examines the effect of capital structure on firm performance in Vietnam, does not find out any statistically significant relationship between two variables. However, this research shows the negative relation between this variable and firm performance. This result is consistent with study of Garriga (2006) that an increase in tangible assets reduces firm performance.

The impact of turnover on firm performance: While Zeitun and Titan (2007) do not figure out any relationship between two variables, this study indicates a statistically significant positive relationship between turnover and firm performance. This is consistent with previous studies that an increase in turnover helps firms increase their profit, but this increase is negligible.

The impact of state ownership (State1) on the firm performance: This variable has statistically significant in all four specifications and has negative relationship to ROA and ROE. State ownership in enterprises is one of characteristics of Vietnamese economy. Son (2008) points out that if the State owns over 50\% of capital in the firm, firm's performance will become worse. This study figures out that if the state just owns more than $35 \%$ of capital of any firm, the firm will be less effective than the rest. Firms having over 35\% State ownership take advantage of accessing to loans with cheaper financial cost than others. However, they may not turn this advantage into reality. It is likely that if firms have more state ownership rate, firms' governance structure becomes heavier. They increase free-riding and their governance system is less flexibility. These outweigh the advantages that the firms take from the state ownership.

The impact of state ownership (State2) on the firm performance: While State1 variable affects both ROE and ROA in four specifications, State 2 variable only impacts negatively on ROE (specification I and II). It is likely that although firms having over $35 \%$ State ownership own large-scale assets and easily access to loans, the use of total assets and equities are both ineffective while firms having 5\%-35\% State ownership use equities ineffectively.

The impact of asset on the firm performance: It is measured by total asset (tangibles and intangibles) to measure the impact of total assets on the firm performance. This study finds out statistically significant relationship between these two variables (excepting specification I) while Son (2008) finds no association. The result in table 2 shows that total assets have positive relationship to ROE while they have negative impact to ROA.

Beside the statistically significant variables explained above, the remaining variable, age, is not statistically significant (excepting specification III).

\section{Conclusions and Recommendations}

\subsection{Conclusion}

This study uses a sample of 465 companies listed in Ho Chi Minh and Ha Noi Stock Exchange in Vietnam, including 1,860 observations in period $2007-2010$ in order to examine the effects of banking relationship on firm performance. The results are summarized as follows:

(i) The more number of bank relationships firms increase, the more firm performance decrease. (ii) Credit financing relationship is one of factors representing banking relationship. This factor includes in three variable such as short-term credit financing relationship, long-term credit financing relationships and overall credit financing relationships. This research points out that if firms establish strong short-term credit financing relationship, their performance will reduce. Inversely, if firms build strong long-term credit financing relationship, they will increase the performance. These imply that focusing on short-term growth is not appropriate for firms while focusing on long-term growth helps firm get better performance. In terms of overall credit financing relationships, firms having the strong relationship use assets ineffectively which lead to the negative association between this variable and ROA. (iii) The increase in total assets during this period through borrowing from banks reduces the effective use of assets but improves financial leverage and these lead to increase in effectiveness of using equity. (iv) Effort on increasing turnover helps firms improve profits. (v) The use of tangible assets through debt financing from financial institutions is ineffective leading to reduction of 
firms' performance. (vi) Currently, Vietnam economy is operating in a so-called "transition stage", and the State still plays a dominant role in the market. One of its manifestations is that the ratio of state ownership in the listed firms is still high. So, firms having over 35\% State ownership are less effective than the others.

\subsection{Recommendations}

Based on the results above, we suggest some recommendations as follows:

(i) Firms should focus on quality of banking relationship rather than trying to establish more number of relationships. Establishing more number of bank relationships in distress period helps firms increasing in number of credit supply resources and solving the hold-up problem, but firms face to the rise of transaction costs, representative cost and free-riding problem. This trade off is negative.

(ii) Firms should improve the efficiency of using bank credit in short-term business activities, and avoid the trap of growing too fast (the growth trap). Once firms overcome the pressure of short-term performance through improving managerial activities, firms will have essential condition concentrating on improving long-term business activities radically. This helps firm grow sustainably and get higher performance.

(iii) Banks should consider "lemon problem" from firms which tend to increase more number of bank relationships. This increase is likely that firms are looking for more sources of credit financing to solve short-term problem in the distress period instead of solving radically business activities. The correct analysis of firms' loan purpose helps banks avoid the "lemons problem" and helps firms not fall into free-riding problem. Banks should also eliminate the routine of easily financing credit to firms which are financed credit from previous banks.

(iv) The State may carefully consider reducing the domination to the economy by reducing ownership rate out of firms which it owns more than $35 \%$ equity, or requiring the State-owned enterprises to reduce State ownership rate out of the firms listed.

\section{References}

Akintoye, I. R. (2008). Effect of capital structure on firms' performance: the Nigerian experience. European Journal of Economics, Finance and Administrative Sciences, 10, 233- 243.

Audretsch, D. B., \& Mahmood, T. (1994). The Rate of Hazard Confronting New Firms and Plants in US Manufacturing. Review of Industrial Organization, 9(1), 41-56. http://dx.doi.org/10.1007/BF01024218

Baltagi, B. H. (2005). Econometric Analysis of Panel Data (3rd ed.). John Wiley \& Sons.

Berger, A. N., \& Udell, G. F. (1998). The Economics of small business finance: the roles of private equity and debt market in the financial growth cycle. Journal of Banking and Finance, 22, 613-673. http://dx.doi.org/10.1016/S0378-4266(98)00038-7

Billett, M. T., Flannery, M. J., \& Garfinkel, J. A. (1995). The effect of lender identity on a borrowing firm's equity return. Journal of finance, 50, 699-718. http://dx.doi.org/10.1111/j.1540-6261.1995.tb04801.x

Bolton, P., \& Freixas, X. (2000). Equity, Bonds, and Bank Debt: Capital Structure and Financial Market Equilibrium under Asymmetric Information. Journal of Political Economy, 108, 324-351. http://dx.doi.org/10.1086/262121

Boot, A. W. A. (2000). Relationship Banking: What Do We Know? Journal of Financial Intermediation, 9, 7-25. http://dx.doi.org/10.1006/jfin.2000.0282

Campbell, T. S. (1979). Optimal invesment financing decisions and the value of confidenciality. Journal of Financial and Quantative Analysis, 14, 232-257.

Castelli, A., Dwyer, G. P. Jr., \& Hasan, I. (2006). Bank relationships and small firms' financial performance. Federal Reserve Bank of Atlanta. Working paper 2006-5.

Dass, N., \& Massa, M. (2006). The Dark Side of Bank-Firm Relationships: The (Market) Liquidity Impact of Bank Lending. Georgia Institute of Technology. Working paper.

Degryse, H., \& Cayseele, P. V. (2000). Relationship Lending within a Bank-Based System: Evidence from European Small Business Data. Journal of Financial Intermediation, 9, 90-109. http://dx.doi.org/10.1006/jfin.1999.0278

Degryse, H., \& Ongena, S. (2001). Bank relationships and firm profitability. Financial Management Spring, 9-34. http://dx.doi.org/10.2307/3666389

Deloof, M., \& Vermoesen, V. (2010). The value of bank relationships: Evidence from Belgium at the start of the 
Great Depression. Working paper. University of Antwerp and Louvain School of Management.

Dhawan, R. (2001). Firm Size and Productivity Differential: Theory and Evidence from a Panel of US Firms. Journal of Economic Behavior \& Organization, 44, 269-293. http://dx.doi.org/10.1016/S0167-2681(00)00139-6

Diamond, D. (1984). Financial Intermediation and Delegated Monitoring. Review of Economic Studies, 51, 393-414. http://dx.doi.org/10.2307/2297430

Diamond, D. (1991). Monitoring and reputation: the choice between bank loans and privately placed debt. Journal of Political Economy, 99, 689-721. http://dx.doi.org/10.1086/261775

Fama, E. (1985). What's Different about Banks? Journal of Monetary Economics, 15, 29-39. http://dx.doi.org/10.1016/0304-3932(85)90051-0

Farinha, A. L., \& Santos, A. C. J. (2001). Switching from single to multiple bank lending relationships: Determinants and implications. Journal of Financial Intermediation, 11(2), 124-151. http://dx.doi.org/10.1006/jfin.2001.0328

Fazzari, S. M., Hubbard, R. G., \& Peterson, B. C. (1988). Financing constraints and corporate investment. Brookings Papers on Economic Activity, 141-206. http://dx.doi.org/10.2307/2534426

Fok, C. W., Chang, Y. C., \& Lee, W. T. (2004). Bank relationships and their effects on firms performance around the asian financial crises: evidence from Taiwan. Financial Management, Summer, 89-112.

Gambini, A., \& Zazzazo, A. (2009). Who captures who? Long-Lasting bank relationships and growth of firms. Università Politecnica delle Marche - Faculty of Economics. Working paper.

Garriga, M. J. (2006). The effect of Relationship Lending on Firm Performance. Department of Business Economics, Universitat Autonoma de Barcelona. Working paper.

Geroski, P. A., \& Mata, J. (2005). Founding Conditions and the Survival of New Firms. Retrieved from http://www.mpiew-jena.mpg.de/english/news/workshops/egpworkshop/Geroski_etal.pdf

Greenbaum, S. I., Kanatas, G., \& Venezia, I. (1989). Equilibrium loan pricing under the bankclient relationship. Journal of Banking Finance, 13, 221-235. http://dx.doi.org/10.1016/0378-4266(89)90061-7

Hiraki, T., Ito, A., \& Kuroki, K. (2003). Single versus Multiple Main Bank Relationships: Evidence from Japan. Social Science Research Network.

Holmstrom, B., \& Tirole, J. (1997). Financial Intermediation, Loanable Funds and the Real Sector. Quarterly Journal of Economics, 112, 663-691. http://dx.doi.org/10.1162/003355397555316

Hoshi, T., Kashyap, A., \& Scharfstein, D. (1991). Corporate structure, liquidity and investment: Evidence from Japanese industrial groups. Quarterly Journal of Economics, 106, 33-60. http://dx.doi.org/10.2307/2937905

Houston, J., \& James, C. M. (1996). Bank information monopolies and the mix of private and public debt choices. Journal of Finance, 51, 1863-1889. http://dx.doi.org/10.1111/j.1540-6261.1996.tb05229.x

James, C. (1987). Some Evidence on the Uniqueness of Bank Loans. Journal of Financial Economics, 19, 217-235. http://dx.doi.org/10.1016/0304-405X(87)90003-1

James, C., \& Weir, P. (1990). Borrowing relationships, intermediation and the cost of issuing public securities. Journal of Financial Economics, 28, 149-171. http://dx.doi.org/10.1016/0304-405X(90)90051-Z

Kutsuna, K., Smith, K. J., \& Smith, L. R. (2003). Banking Relationships and Access to Equity Capital Markets: Evidence from Japan's Main Bank System. Claremont Colleges. Working paper.

Mata, J., \& Portugal, P. (1994). Life duration of new firms. The Journal of Industrial Economics, 42(3), 227-245. http://dx.doi.org/10.2307/2950567

Park, H. M. (2009). Linear Regression Models for Panel Data Using SAS, Stata, LIMDEP, and SPSS. Working paper. Indiana University.

Peltoniemi, J. (2004). The Value of Relationship Banking: Empirical evidence on small business financing in Finnish credit markets. Faculty of Economics and Business Administration, Department of Accounting and Finance, University of Oulu.

Petersen, M., \& Rajan, R. (1995). The Effect of Credit Market Competition on Lending Relationships. Quarterly Journal of Economics, 110, 406-443. http://dx.doi.org/10.2307/2118445

Petrunia, R. (2002). Start-up Conditions and the Post-Entry Experience of New Firms. Retrieved from 
http://www.sauder.ubc.ca/research/research_centres/era/arena1/papers/paper\%202.pdf

Rajan, R. G. (1992). Insiders and outsiders: the choice between informed and arm's length debt. Journal of Finance, 47, 1367-1400. http://dx.doi.org/10.1111/j.1540-6261.1992.tb04662.x

Ramirez, C. (1995). Did J.P. Morgan's men add liquidity? Corporate investment, cash flow, and financial structure at the turn of the twentieth century. Journal of Finance, 50, 661-678. http://dx.doi.org/10.1111/j.1540-6261.1995.tb04799.x

Sharpe, S. A. (1990). Asymmetric information, bank lending and implicit contracts: a stylized model of customer relationships. Journal of Finance, 45, 1069-1087.

Shen, C. H., \& Wang, C. A. (2004). Does bank relationship matter for a firm's investment and financial contraints? The case of Taiwan. Pacific Basin Financial Journal, 13, 163-184. http://dx.doi.org/10.1016/j.pacfin.2004.07.004

Slovin, M. B., \& Young, J. E. (1990). Bank lending and initial public offerings. Journal of banking and finace, 14, 729-740. http://dx.doi.org/10.1016/0378-4266(90)90073-B

Sơn, T. H. (2008). Co cấu vốn và hiệu quả hoạt động doanh nghiệp của các công ty niêm yết trên SGDCK TPHCM. Tạp chí Phát triển Kinh tế - Đại học Kinh tế Tp. HCM, 12.

Stinchcombe, A. L. (1965). Social structure and organizations (J.G ed.). Handbook of Organizations, Chicago, Rand McNally.

Suwanaporn, C. (2003). Determinants of Bank Lending in Thailand: An Empirical Examination for the Years 1992 to 1996. Peter Lang Publishing.

von Thadden, E. L. (1995). Long term contracts, short term investment, and monitoring. Review of Economic Studies, 62, 557-575. http://dx.doi.org/10.2307/2298077

Weinstein, D., \& Yafeh, Y. (1998). On the Costs of a Bank-Centered Financial System: Evidence from the Changing Main Bank Relations in Japan. Journal of Finance, 53, 635-672. http://dx.doi.org/10.1111/0022-1082.254893

Yosha, O. (1995). Information disclosure costs and the choice of financing source. Journal of financial intermediation, 4, 3-20. http://dx.doi.org/10.1006/jfin.1995.1001

Zeitun, M., \& Tian, G. G. (2007). Capital Structure and Corporate performance: Eviden from Jordan. Australasian Accounting Bisness and Finace Journal, I(4). 